\title{
COMMENTS
}

\section{Truth in Sentencing: The Prospective and Retroactive Application of Simmons $v$ South Carolina}

\author{
Benjamin P. Cooper $\dagger$
}

A jury's awareness about a defendant's eligibility for parole can have a profound effect on the sentence that it imposes on the defendant. Empirical studies show that this knowledge can literally be a matter of life and death. A typical "death qualified" juror ${ }^{1}$ believes that a "life sentence" carries with it a possibility of parole, and, as a result, is more likely to sentence the defendant to death. ${ }^{2}$ This phenomenon presents a compelling fairness rationale for fully informing all capital juries of the defendant's

$\dagger$ B.A. 1994, Amherst College; J.D. Candidate 1997, The University of Chicago.

1 All jurors in capital cases must be "death qualified." That is, they must be willing to impose the death penalty. Those morally opposed to the death penalty are not allowed to be on capital juries and are screened out at voir dire.

${ }_{2}$ See Theodore Eisenberg and Martin T. Wells, Deadly Confusion: Juror Instructions in Capital Cases, 79 Cornell L Rev 1, 7-9 (1993) ("Jurors who believe the alternative to death is a relatively short time in prison tend to sentence to death."); W. Bowers, Capital Punishment and Contemporary Values: People's Misgivings and the Court's Misperceptions, 27 L \& Soc'y Rev 157, 167-71 (1993) ("[J]urors who underestimate the currently available alternative are more apt to impose the death penalty."); William M. Hood, III, Note, The Meaning of "Life" for Virginia Jurors and Its Effect on Reliability in Capital Sentencing, 75 Va L Rev 1605, 1606, 1620-25 (1989) (recounting survey that found that "residents of Prince Edward County, Virginia, who are eligible for capital juries ... [b]elieve that a capital defendant sentenced to life imprisonment will likely serve only ten years before being released on parole"). See generally Anthony Paduano and Clive A. Stafford Smith, Deathly Errors: Juror Misperceptions Concerning Parole in the Imposition of the Death Penalty, 18 Colum Hum Rts L Rev 211, 211-14 (1987) (asserting that jurors who are 'laboring under this misconception that a sentence of 'life' is a ticket to 'get out of jail free" are more likely to vote for death). 
parole status. Several states, however, left by the Supreme Court to decide this issue for themselves, ${ }^{3}$ have chosen not to give juries this information. Even when juries care enough to inquire specifically about a defendant's parole status, judges in these states decline to answer.

Recognizing this phenomenon, the Supreme Court delivered a simple and noncontroversial opinion in Simmons $v$ South Carolina. ${ }^{4}$ The Court held that when the prosecutor rests his case for the death penalty on the defendant's future dangerousness, and where the defendant is ineligible for parole, due process requires that the jury be informed that the defendant is ineligible for parole, even though state law otherwise prevents the jury from considering parole eligibility. ${ }^{5}$ Although the justices disagreed on the Constitutional basis for the decision and the scope of the rule announced, ${ }^{6}$ the case was not a difficult one: A prosecutor must not be able to mislead jurors into believing that the defendant, who will never be eligible for parole, will one day pose a danger to society if not sentenced to death. In dissent, Justices Scalia and Thomas agreed that there was a need to avoid prosecutorial misconduct but did not agree that it had occurred in this case.

While the Supreme Court faced a rather easy decision in Simmons, lower courts have confronted a much more difficult task in addressing the dozens of Simmons claims that have subsequently come before them. These claims come in two varieties. First, defendants whose convictions were not final at the time of the Simmons decision seek the benefit of the rule in Simmons on direct appeal. ${ }^{7}$ Second, defendants whose convictions were final at the time of Simmons seek to use it to make a collateral attack on their death sentences.

${ }^{3}$ See California $v$ Ramos, 463 US 992, 1014 (1983) ("[T]he wisdom of the decision to permit juror consideration of [post-sentencing contingencies] is best left to the States.").

- 114 S Ct 2187 (1994).

5 Id at 2195-96 (plurality).

- Six justices decided the case under the Due Process Clause of the Fourteenth Amendment. Justice Souter, concurring, thought that the Eighth Amendment also mandated the result. See Sections I.A. and I.B.

7 A conviction becomes final when the defendant has exhausted his direct appeals. Until the conviction becomes final, the defendant can benefit from any case law creating new rules for the conduct of criminal prosecutions without having to worry about issues of retroactivity. Griffith $v$ Kentucky, 479 US 314, 328 (1987). For instance, a defendant who was convicted prior to the Simmons decision but whose direct appeal had not yet been heard when the Court decided Simmons could raise a Simmons claim. 
With respect to the first type of claim, the Simmons decision left a number of questions unanswered. What, for example, constitutes an argument about a defendant's future dangerousness? Must a defendant have been technically ineligible for parole or practically ineligible for parole? Is eligibility at the age of 125 good enough? Finally, must the defendant have objected to the argument in order to preserve it for appeal?

According to Justice Souter's concurring opinion, the Eighth Amendment's requirement of heightened reliability in capital cases mandates that juries know all relevant information about a capital defendant, including parole availability. ${ }^{8}$ It follows that Simmons should be applied generously to cases on direct appeal. Despite Justice Souter's logic and the arguments of commentators, ${ }^{9}$ however, the majority of lower courts have read Simmons quite narrowly. With only a few exceptions, courts have refused to apply Simmons unless the defendant is technically ineligible for parole, the prosecutor rests his case for the death penalty on the defendant's future dangerousness, and the defense attorney raises a timely objection or asks for an instruction.

After reviewing cases brought under the first type of claim, this Comment focuses on the second type of claim arising from Simmons: those from defendants whose convictions were final at the time of Simmons. These defendants seek to use Simmons to make a collateral attack on their death sentences, that is, to challenge the validity of their sentencing after they have exhausted their direct appeals. With respect to these claims, the fundamental question is whether Simmons should be applied retroactively.

The retroactivity of Simmons in a federal habeas claim must be examined under the exacting standard of 28 USC $\S 2254$ (d), as recently amended..$^{10}$ The new habeas statute provides that federal courts may not grant relief to state prisoners "unless the [state court] adjudication of the claim ... resulted in a decision that was contrary to, or involved an unreasonable application of clear-

8 Simmons, 114 S Ct at 2198-99 (Souter concurring).

- See, for example, Janie Clark, Note, Putting an End to the Imposition of Death by Misperception and Misunderstanding: Simmons v. South Carolina, 43 U Kan L Rev 1147 (1995).

10 Antiterrorism and Effective Death Penalty Act of 1996, § 104(3), Pub L No 104-132, 110 Stat 1214, 1219 (1996). After exhausting their direct appeals, state prisoners have two avenues of recourse. First, they may seek relief under state post-conviction relief statutes. Then, they may seek federal habeas relief. 28 USC $\$ 2254$ (d) sets the retroactivity standard only for federal habeas claims. States are free to set their own retroactivity standards, although many follow the federal habeas standard. 
ly established Federal law, as determined by the Supreme Court of the United States." Although Congress did not explicitly say so, the new statute appears to codify the Supreme Court's controversial decision in Teague $v$ Lane. ${ }^{12}$ In Teague, the Court severely limited the number of rules that apply retroactively in habeas cases. Under Teague, "new rules" of law will not be applied retroactively; ${ }^{13}$ a rule is "new" if the result was not "dictated" by precedent. $^{14}$ Teague also provided two exceptions, which the new statute has apparently preserved, ${ }^{15}$ under which new rules will be applied retroactively. One exception, perhaps applicable to Simmons, is for "watershed rules of criminal procedure" that affect the accuracy of the sentence. ${ }^{16}$ Despite some strong dicta, under which everything would be a new rule and nothing would

1128 USC $\$ 2254(\mathrm{~d})(1)$.

12489 US 288, 307-10 (1989). Teague itself was about retroactivity; that is, Teague addressed when a defendant can benefit from a legal decision handed down after his conviction became final. The new statute apparently makes Teague the standard of review on habeas for all state court determinations of federal law. In Wright $v$ West, 505 US 277, 291 (1992) (plurality), Justice Thomas anticipated this development, describing Teague as establishing a "deferential" standard of review for state court determinations of federal law. See text accompanying notes 104-06. Congress did not address this issue and said very little to clarify its intent in revising § 2254(d). In Lindh v Murphy, 1996 US App LEXIS 24136 (7th Cir) (en banc), however, Judge Easterbrook examined the relationship between Teague and $\S 2254(\mathrm{~d})$. Judge Easterbrook described § 2254(d)(1) as "codif[ying] and extend[ing] the Teague standard." Id at *44. He explained:

The novelty in this portion of $\$ 2254$ (d)(1) is not the 'contrary to' part but the reference to 'Federal law, as determined by the Supreme Court of the United States.' This extends the principle of Teague by limiting the source of doctrine on which a federal court may rely in addressing the application for a writ.

Id at. $* 3^{*}$. In order to secure a writ under the new standard, therefore, a habeas petitioner must point to an "authoritative decision of the Supreme Court." Id at *34. Because I argue that Simmons was compelled by two Supreme Court decisions, the new statute, as interpreted by the Seventh Circuit, does not alter my analysis. The Seventh Circuit's conclusion that the new standard codifies Teague is not surprising since the courts have struggled for seven years to work out the kinks in Teague and because Teague is firmly established as the retroactivity standard. Given this history, other courts are likely to follow Lindh. When I refer to the Teague standard in this Comment, I am referring to the § 2254(d) standard. A more detailed discussion of $\S 2254$ (d) and its relationship to Teague is beyond the scope of this Comment.

13489 US at 310 (plurality).

14 Id at 301. As Section II.A. and II.B. explain, the exact definition of these terms has been the subject of heated debate in the Supreme Court.

${ }_{15}$ See 28 USC $\S 2254(e)(2)$. Under the new statute, a petitioner can at least gain an evidentiary hearing if his claim relies on a "new rule of constitutional law, made retroactive to cases on collateral review by the Supreme Court, that was previously unavailable...."

${ }^{16}$ See also Teague, 389 US at 313 (plurality) (discussing scope of exception); Sawyer $v$ Smith, 497 US 227, 241 (1990). 
apply retroactively, ${ }^{17}$ the Court has not made the Teague bar insurmountable. In fact, in two of the three capital cases involving retroactivity issues since Teague, the Court has applied rules retroactively.

Whether courts will apply Simmons retroactively remains uncertain. In opinions beset with confusion, lower courts have misapplied Teague and reached inconsistent results. Courts should resolve the disagreement by applying Simmons retroactively under either of two rationales. Under the first rationale, courts should apply Simmons retroactively because it is not a new rule-a careful analysis of Simmons and its precedents shows that the Court's holding was dictated by Gardner $v$ Florida ${ }^{18}$ and Skipper $v$ South Carolina. ${ }^{19}$ Alternatively, even if the Court were to find that Simmons is a new rule, it should nevertheless apply Simmons retroactively. Empirical studies demonstrate that the application of the Simmons rule has an effect on the sentence imposed by the jury. ${ }^{20}$ Because inmates sit on death row as a result of judges' refusals to remedy misleading prosecutorial arguments with accurate sentencing information, the Simmons rule should apply retroactively under Teague's "watershed rule" exception.

Section I of this Comment lays out the facts of Simmons and examines the plurality, concurring, and dissenting opinions. This Section then describes the lower courts' treatment of Simmons claims arising on direct appeal and identifies the scope of the rule announced in Simmons. Section II of this Comment then sets out the Court's retroactivity doctrine. Finally, Section III argues that Simmons should be applied retroactively, even under the exacting standard of 28 USC $\S 2254(d)$.

\section{The SUPREME CourT's DECISION IN SIMMONS V SOUTH}

\section{CAROLINA}

Simmons was charged with the first-degree murder of seventy-nine year-old Josie Lamb. Because Simmons confessed to sexually and physically assaulting elderly women on three prior

${ }^{17}$ See, for example, Butler $v$ McKellar, 494 US 407, 415 (1990) (concluding that because prior decision was "susceptible to debate among reasonable minds" it announced a "new" rule).

18430 US 349 (1977).

19476 US 1 (1986).

${ }^{20}$ See note 2 and accompanying text. 
occasions, under South Carolina law, he was ineligible for parole if convicted. ${ }^{21}$

At trial, the jury convicted Simmons of first-degree murder, rendering him ineligible for parole. At sentencing, the prosecutor urged the jury to consider Simmons's future dangerousness in deciding his punishment. Specifically, the prosecutor argued that the "question for the jury ... was 'what to do with [petitioner] now that he is in our midst." He added that a death sentence "would be a response of society to someone who is a threat. Your verdict will be an act of self-defense."22 Simmons's counsel requested a jury instruction explaining that a life sentence meant Simmons could not be released on parole. The judge refused. ${ }^{23}$

Clearly, though, the jury was concerned about Simmons's eligibility for parole. After ninety minutes of deliberation, the jury sent a note to the judge asking: "Does the imposition of a life sentence carry with it the possibility of parole?" The judge replied that parole was not an issue for the jury to consider and that "[t]he terms life imprisonment and death sentence are to be understood in their plan [sic] and ordinary meaning." Twenty-five minutes later the jury returned a sentence of death. ${ }^{24}$

To determine exactly what the Supreme Court held in Simmons-and how courts should read Simmons in future cases-requires sorting through the four different opinions. Justice Blackmun's plurality opinion contains broad language that would impose a number of requirements on the trial judge and the prosecutor. Justice O'Connor's and Justice Ginsburg's concurring opinions, as well as Justice Scalia's dissent, however, specifically repudiate this broad language and confine the holding to its facts. Under these three opinions, Simmons would provide relief to defendants only under very specific circumstances.

${ }^{21}$ Simmons, $114 \mathrm{~S} \mathrm{Ct}$ at 2190. Eligibility for parole is governed by state law. In South Carolina, "[t]he board [of Probation, Parole and Pardon] must not grant parole nor is parole authorized to any prisoner serving a sentence for a second or subsequent conviction, following a separate sentencing for a prior conviction, for violent crimes . .. ${ }^{n}$ SC Code Ann § 24-21-640 (Law Co-op 1989 \& Supp 1995).

22 Simmons, 114 S Ct at 2190-91. Significantly, the prosecutor made only generalized arguments about Simmons's future dangerousness. He did not explicitly argue to the jury that Simmons would kill again if they did not give him the death penalty.

${ }^{23}$ Id at 2191-92. Under South Carolina law, a jury is not to receive any information about the defendant's parole eligibility. State $v$ Norris, 285 SC 86, 328 SE2d 339 (1985). Pursuant to South Carolina law, prior to jury selection, the trial judge granted the State's motion to prohibit the defense from mentioning the subject of parole or asking prospective jurors whether they understood what "life imprisonment" meant under South Carolina law. Simmons, 114 S Ct at 2190.

${ }^{24}$ Simmons, $114 \mathrm{~S}$ Ct at 2192. 


\section{A. Justice Blackmun's Plurality Decision}

Writing for a four-justice plurality, Justice Blackmun overturned Simmons's conviction under the Due Process Clause of the Fourteenth Amendment. Justice Blackmun wrote that "where the defendant's future dangerousness is at issue, and state law prohibits the defendant's release on parole, due process requires that the sentencing jury be informed that the defendant is parole ineligible."25

The plurality relied on two earlier Supreme Court decisions, Gardner $v$ Florida $a^{26}$ and Skipper $v$ South Carolina. ${ }^{27}$ In Gardner, the trial judge sentenced the defendant to death based on a pre-sentence investigative report that the defendant did not have an opportunity to see. The Court held that the defendant was denied due process of law because his sentence "was imposed, at least in part, on the basis of information which [the defendant] had no opportunity to deny or explain."${ }^{\text {"28 }}$ In Skipper, the trial judge had refused to admit evidence of the defendant's good behavior in prison during the sentencing phase of the trial. Citing Gardner, the Skipper Court held that "[w] cution specifically relies on a prediction of future dangerousness in asking for the death penalty," both the Eighth Amendment and the Due Process Clause require the admission of evidence showing "that the defendant would not pose a danger if spared (but incarcerated). ${ }^{29}$

The plurality in Simmons concluded that the defendant had been sentenced to death on the basis of information he had no opportunity to "deny or explain," in violation of the Due Process Clause. They reasoned that Simmons was sentenced to death, at least in part, on the basis of the prosecution's future dangerousness arguments that the defendant had no opportunity to rebut. $^{30}$

${ }^{25}$ Id at 2190 (plurality). Justice Blackmun was joined by Justices Stevens, Souter, and Ginsburg.

26430 US 349 (1977).

27476 US 1 (1986).

28 Gardner, 430 US at 362.

29 Skipper, 476 US at 5 \& $\mathrm{n} 1$.

${ }^{30}$ Simmons, $114 \mathrm{~S} \mathrm{Ct}$ at 2192-93 (plurality). The plurality declined to consider whether the Eighth Amendment also mandated the decision. Id at $2193 \mathrm{n} 4$. 


\section{B. Concurring Opinions}

Justice Souter, joined by Justice Stevens, wrote separately to emphasize his belief that the outcome in the case was also mandated by the Eighth Amendment, insofar as it requires a heightened standard of reliability in capital cases. As part of this heightened standard, jurors must fully comprehend their sentencing options. ${ }^{31}$ The Eighth Amendment therefore "mandates recognition of a capital defendant's right to require instructions on the meaning of the legal terms used to describe the sentences ... a jury is required to consider. ${ }^{\text {"32 }}$

Justice Souter also said that a mere argument by defense counsel was not sufficient to satisfy the demands of the Eighth Amendment. Instead, the Eighth Amendment mandates that the trial judge instruct the jury regarding parole eligibility. ${ }^{33}$ This is similar to Justice Blackmun's instruction that the jury must be "informed" of the defendant's parole eligibility. ${ }^{34}$ These opinions, therefore, indicate that a prosecutor's future-dangerousness argument will not only open the door for a defense counsel argument but will compel the trial judge, in the absence of such an argument, to instruct the jury regarding the defendant's eligibility for parole. ${ }^{35}$

Justice Ginsburg and Justice O'Connor each wrote separately to emphasize the narrowness of the Court's holding. For Justice Ginsburg, this case involved the "core requirement of due process, the right to be heard." ${ }^{36}$ This requirement is satisfied if the defense counsel is given the opportunity to rebut the future-dangerousness argument. ${ }^{37}$

Justice O'Connor, joined by Chief Justice Rehnquist and Justice Kennedy, also wrote separately-probably in reaction to the potentially broad scope of the Court's language. Although she never explicitly disagreed with anything in the plurality opinion, Justice O'Connor identified the applicable precedents and characterized the holding of the case in a narrow manner. ${ }^{38}$ She wrote,

31 Id at 2198 (Souter concurring).

32 Id.

33 Id at 2198-99.

34 Simmons, 114 S Ct at 2190 (plurality).

${ }^{35}$ In fact, Justice Souter said that the Eighth Amendment's heightened standard for capital cases requires the trial judge to instruct the jury on the defendant's parole eligibility in every such case. Simmons, $114 \mathrm{~S} \mathrm{Ct}$ at 2198-99 (Souter concurring).

${ }^{36}$ Simmons, $114 \mathrm{~S}$ Ct at 2199 (Ginsburg concurring).

37 Id.

${ }^{38}$ Simmons, $114 \mathrm{~S} \mathrm{Ct}$ at 2200-01 (O’Connor concurring). 
"Where the State puts the defendant's future dangerousness in issue, and the only available alternative sentence to death is life imprisonment without the possibility of parole, due process entitles the defendant to inform the capital sentencing jury-by either argument or instruction-that he is parole ineligible. ${ }^{39}$

\section{Justice Scalia's Dissent}

Although the exact basis of Justice Scalia's dissent is unclear, he appears to have disagreed with the plurality primarily on factual grounds. Justice Scalia, joined by Justice Thomas, acknowledged the plurality's basic premise-that a defendant may not be sentenced to death on the basis of information he has no opportunity to deny or explain..$^{40}$ In Justice Scalia's view, however, Simmons did not present such a factual situation. Instead, he concluded, "it was the sheer depravity of those crimes, rather than any specific fear for the future, which induced the South Carolina jury to conclude that the death penalty was justice. ${ }^{{ }^{41}}$ Moreover, Justice Scalia argued that the reference to "self-defense" alluded to all members of society, including other prisoners. ${ }^{42}$

Like Justice Ginsburg, Justice Scalia expressed concern about the breadth of the plurality opinion: "It purports to be a determination that any capital-sentencing scheme that does not permit jury consideration of [parole eligibility] is so incompatible with our national traditions of criminal procedure that it violates the Due Process Clause .... ${ }^{n 3}$ Since the "national practice"-or at least the practice of many states-is not to inform the jury about parole, a defendant has no due process right to have the jury so informed. ${ }^{44}$ Justice Scalia would only find a constitutional mandate to inform the jury of the defendant's parole ineligibility if the prosecutor makes an argument about parole..$^{45}$

39 Id at 2201.

40 Simmons, $114 \mathrm{~S} \mathrm{Ct}$ at 2202 (Scalia dissenting).

41 Id at 2202-03. If Scalia's dissent is really based on factual grounds, then arguably the Court unanimously approved at least a narrow rule allowing the defendant to raise parole ineligibility when the prosecutor rests his case for death on an argument of future dangerousness outside of prison. See text accompanying note 133.

12 Id at 2203.

43 Id at 2201.

4 Id at 2201-02.

45 Id at 2204. 


\section{Simmons in the Lower Courts}

This Section examines the impact of the rule in Simmons by identifying which group of defendants has actually benefited from the Court's decision in Simmons. ${ }^{46}$ Understanding the impact and scope of the rule lays the foundation for the discussion in Section III about retroactivity in two respects. First, examination of the lower courts' narrow reading of Simmons identifies who would benefit from the retroactive application of the rule. Second, the narrow scope of the rule provides a reason why courts should apply it retroactively: since the rule applies only to a small class of prisoners, retroactive application would not produce a flood of claims.

\section{State court parole eligibility.}

Understanding the impact of Simmons requires an appreciation of the way state courts treat information about parole eligibility. Prior to Simmons, the Supreme Court provided little guidance as to what information was proper for a jury to have. Although common sense might indicate that a jury should always be informed of a defendant's parole eligibility, ${ }^{47}$ the Court generally left this determination to the states, ${ }^{48}$ and the states have developed quite different policies. A brief examination of these policies indicates that the impact of Simmons will be limited to a handful of states.

${ }^{46}$ Several commentators have discussed the Simmons decision, but mostly in terms of what the impact of the decision should be, rather than what the impact actually has been or will be. See Clark, Note, 43 U Kan L Rev at 1148 (cited in note 9) (arguing that "[t]he Court should have held that the Eighth and Fourteenth Amendments require a capital sentencing jury to be informed, upon request of either prosecution or defense, of a defendant's parole status"); John Christopher Johnson, Note, When Life Means Life: Juries, Parole, and Capital Sentencing, 73 NC L Rev 1211, 1233 (1995) (arguing that the Supreme Court should have decided the case under the Eighth Amendment because "due process only allows a jury instruction on parole ineligibility when the prosecution argues future dangerousness of the defendant, whereas the Eighth Amendment holding would require such an instruction whenever the jury is likely to be confused about the defendant's parole status"). One commentator noted the early impact of Simmons in the lower courts but still focused on the Simmons decision itself. See Mary Zaug, Note, Simmons v. South Carolina: Safeguarding a Capital Defendant's Right to Fair Sentencing, 26 Loyola U Chi L J 511, 513 (1995) (arguing that the Supreme Court "may eventually extend Simmons to require states to allow capital defendants to inform sentencers of parole ineligibility in all cases").

47 Even Justice Scalia admitted as much in his Simmons dissent: "[T]he regime imposed by today's judgment is undoubtedly reasonable as a matter of policy ...." Simmons, 114 S Ct at 2205 (Scalia dissenting).

4 California v Ramos, 463 US 992, 1014 (1983). 
The forty-one states that currently have the death penalty fall into distinct categories. Eight states mandate that the court inform the jury of a capital defendant's parole status or at least allow defense counsel to do so at his discretion. ${ }^{49}$ In five other states, a judge or panel of judges decides whether a defendant will receive a capital sentence. ${ }^{50}$ In these thirteen states, then, the sentencing authority is aware of the precise parole status of defendants. Simmons will therefore have no impact on the capital sentencing procedures in any of these states.

In ten other states, the jury may choose only between death and life imprisonment without the possibility of parole. ${ }^{51}$ Here again Simmons is inapplicable since the jury is presented with only two choices, neither of which includes the possibility for parole.

Eight states allow the jury to decide whether a defendant should receive the death penalty or some variation of life imprisonment. ${ }^{52}$ Simmons is unlikely to have an impact in any of

19 The eight states are Georgia, see Ga Code Ann § 17-10-31.1(d) (Michie Supp 1995); Florida, see Standard Jury Instructions-Criminal Cases, No. 92-1, 603 S2d 1175, 1201 (Fla 1992) (jury informed that sentencing options are death or life in prison without possibility of parole for 25 years); Illinois, see People $v$ Gacho, $122 \mathrm{Il} 2 \mathrm{~d} 221,522$ NE2d 1146, 1166 (1988) (jury informed that options are death or natural life, which means no possibility for parole but possibility of executive clemency); Mississippi, see Turner $v$ State, 573 S2d 657, 673-75 (Miss 1990) (holding that at the sentencing phase, "the jury shall be entitled to know by instruction whether the defendant is eligible for parole"); New Jersey, see State $v$ Martini, 131 NJ 176, 619 A2d 1208, 1277-80 (1993), cert denied 116 S Ct 203 (1995) (Jury must be fully informed of defendant's prior sentences either on the defendant's request or in the event of a jury inquiry.); New Mexico, see Clark $v$ Tansy, 118 NM 486, 882 P2d 527, 533 (1994) (Jury must be informed if the prosecution raises future dangerousness, and if the defense so requests.); and North Carolina, see NC Gen Stat § 15A-2002 (Michie 1988 \& Supp 1995) ("The judge shall instruct the jury . . . that a sentence of life imprisonment means a sentence of life without parole.").

In Maryland, the defense has the option to inform the jury of the defendant's eligibility for parole. Doering $v$ State, 313 Md 384, 545 A2d 1281, 1295 (1988). If Simmons were read to mandate a trial court instruction, and not a defense counsel argument, the Maryland procedure might be impacted.

${ }_{50}$ The five states are Arizona, see Ariz Rev Stat Ann § 13-703(B) (West 1989 \& Supp 1995); Colorado, see Colo Rev Stat § 16-11-103(1)(a) (West 1990 \& Supp 1995); Idaho, see Idaho Code § 19-2515 (Michie 1987 \& Supp 1995); Montana, see Mont Code Ann § 46-18301 (1995); and Nebraska, see Neb Rev Stat \& 29-2520 (1985).

${ }_{51}$ The ten states are Alabama, see Ala Code \$ 13A-5-46(e) (Michie 1994); Arkansas, see Ark Code Ann § 5-4-603(a), (b) (Michie 1993); California, see Cal Penal Code § 190.3 (West 1988); Connecticut, see Conn Gen Stat Ann § 53a-46a(f) (West 1994 \& Supp 1995); Delaware, see 11 Del Code Ann § 4209(a) (Michie 1995); Indiana, see Ind Code Ann § 35 50-2-9 (West 1986 \& Supp 1995); Louisiana, see La Code Crim Proc Ann art 905.6 (West 1984 \& Supp 1996); Missouri, see Mo Ann Stat $\S 565.030$ (Vernon Supp 1996); New Hampshire, see NH Rev Stat Ann § 630:5 (Equity 1986 \& Michie Supp 1995); and Washington, see Wash Rev Code Ann $\S 10.95 .030$ (West 1990 \& Supp 1996).

${ }^{32}$ The eight states are Kentucky, Ky Rev Stat Ann $\S 532.030$ (Michie 1990); Nevada, 
these states either. This is because, in light of the jury's ability to choose among at least three options, the defendant is, technically, eligible for parole. Of course, a court in one of these states could read Simmons as Justice Souter does and require that a jury be informed of the defendant's parole status in every instance.

Six states allow the jury to choose between death and life imprisonment, without specifying what life imprisonment means. Among these states, all but Kansas do not permit the jury to be informed about defendants' parole ineligibility. ${ }^{53}$ Simmons should have the greatest impact in these states. ${ }^{54}$ However, as the following discussion will make clear, even in these states, the impact is limited.

\section{Limited applicability in the lower courts.}

Having identified the states in which Simmons can have an impact, the discussion turns to what exactly this impact has been. In his Simmons dissent, Justice Scalia expressed his fear that the Simmons decision was "the first page of a whole new chapter in the 'death-is-different' jurisprudence. ${ }^{555} \mathrm{He}$ criticized the Court for creating a "Federal Rules of Death Penalty Evidence," rules that the Court would craft "at great expense to the swiftness and predictability of justice. ${ }^{556}$

So far, Justice Scalia's fears have proven misplaced. Instead of following the spirit of the decision, most lower courts have applied Simmons formalistically and only to a narrow class of

see Nev Rev Stat § 175.554 (1995); New York, see NY Crim Pro Law § 400.27 (10) (McKinney Supp 1996); Ohio, see Ohio Rev Code Ann § 2929.03(C)(2) (Baldwin 1993 \& Supp 1996); Oklahoma, see 21 Okla Stat Ann § 701.I0 (West 1983 \& Supp 1996); Oregon, see Or Rev Stat § 163.105 (Supp 1994); Tennessee, see Tenn Code Ann § 39-13-204(a) (Michie 1991 \& Supp 1995); and Utah, see Utah Code Ann \& 76-3-207(4) (Michie 1995) (Jurors first vote on death. If they do not vote unanimously in favor of death, they vote on life in prison without possibility of parole. If they do not vote unanimously for this option, the judge sentences the defendant to life in prison with the possibility for parole.).

${ }_{53}$ The six states are Kansas, see Kan Stat Ann $\$ \S 21-4624,21-4706$ (c) (1995); North Dakota, see State v Peltier, 21 ND 188, 129 NW 451, 452 (1910); Pennsylvania, see Commonwealth $v$ Henry, $524 \mathrm{~Pa}$ 135, 569 A2d 929, 941 (1990); South Carolina, see State v Norris, 285 SC 86, 328 SE2d 339 (1985); Texas, see Jones $v$ State, 843 SW2d 487, 495 (Tex Crim App 1992), cert denied 507 US 1035 (1993); and Virginia, see Eaton v Commonwealth, $240 \mathrm{Va} 236,397$ SE2d 385, 392 (1990).

5t Two other states have not made a decision regarding what parole information a jury should receive. The two states are South Dakota, see SD Cod Laws § 24-15-4 (Michie 1988); and Wyoming, see Wyo Stat §§ 6-2-101(b) (Michie 1988 \& Supp 1995), 7-13-402(a) (Michie 1995).

${ }^{35}$ Simmons, $114 \mathrm{~S} \mathrm{Ct}$ at 2205 (Scalia dissenting).

56 Id at 2205. 
cases. ${ }^{57}$ These courts have found a number of different ways to limit the applicability of Simmons.

\section{Future dangerousness argument required.}

First, courts have required that, in order for Simmons to apply, the prosecutor must build his case for the death penalty on the defendant's future dangerousness. ${ }^{58}$ In so doing, these courts have rejected Justice Souter's Eighth Amendment argument that a jury must always be informed of a defendant's parole status. Since the plurality refused to decide the issue, this limit on Simmons is not surprising.

\section{The requirement of technical parole ineligibility.}

Second, lower courts have applied Simmons only where the defendant is technically ineligible for parole. These courts refuse to apply Simmons to the defendant who receives a sentence that will keep him in jail until the age of 150 , rendering him practically ineligible for parole, if not legally ineligible. In State $v$ McLaughlin, for example, the Supreme Court of North Carolina refused to find error, where, during deliberation, the trial judge refused to answer the jury's question about whether the imposition of three consecutive life sentences would render the defendant ineligible for parole. ${ }^{59}$

57 Thus far, only one court has given Simmons the kind of broad reading urged by commentators and feared by Justice Scalia. In Clark v Tansy, 118 NM 486, 882 P2d 527, 529-30 (1994), the New Mexico Supreme Court remanded the defendant's case after the prosecutor relied on Clark's future dangerousness in his argument for the death penalty. The defendant was not legally eligible for parole until the age of 86 . Citing the concurring opinion of Justice Souter, the New Mexico court held that:

The length of incarceration facing a capital defendant before he can be considered for parole, as an alternative to a death sentence, is information that must be provided to a jury before it deliberates on the capital charge if the defendant decides it is in his best interest to have the jury apprised of this information.

Id at 533.

s8 See People v Franklin, 167 Ill 2d 1, 656 NE2d 750, 760 (1995), cert denied 116 S Ct 1357 (1996) (rejecting Simmons claim because "the prosecution did not place the defendant's future dangerousness at issue during the second stage of the sentencing hearing"); State $v$ Southerland, 447 SE2d 862, 868 (SC 1994), cert denied 115 S Ct 1136 (1995), overruled on other grounds, State v Chapman, 454 SE2d 317, 320 (SC 1995) ("Here, the solicitor specifically agreed not to argue Southerland's future dangerousness."); Fleming $v$ State, 265 Ga 541, 458 SE2d 638, 639-40 (1995) (Trial court's refusal to allow defendant to use expert testimony to rebut prosecution's statement that sentencing appellant to death will deter others from crime does not fall under rationale of Simmons.).

s9 State $v$ McLaughlin, 341 NC 426, 462 SE2d 1, 16 (1995), cert denied 116 S Ct 956 
Similarly, in Allridge $v$ Scott, the Fifth Circuit refused to allow the defendant to present expert testimony that he would almost certainly be ineligible for parole. ${ }^{60}$ The court said that the defendant's parole ineligibility was a "matter of fact" not a "matter of law," explaining that "the Court made clear in Simmons [that] the Togic and effectiveness of petitioner's argument naturally depended on the fact that he was legally ineligible for parole."'61 The court concluded that evidence that a defendant is ineligible for parole as a matter of law is "inherently "truthful" and can "positively deny future dangerousness," whereas evidence of ineligibility as a matter of fact is "purely speculative." ${ }^{\prime 62}$

Although this analysis might apply where the defendant could indeed come up for parole in 20 or 30 years, such a mechanical application of Simmons is illogical if the defendant would not come before a parole board for 100 years. Moreover, if the prosecution makes an argument that the defendant might pose a threat to society, the defendant should be able to respond with the argument that he might never be released on parole. After all, if a defendant is ineligible for parole until age 120, the likelihood of his release on parole is no more speculative than an argument that he will pose a future threat to society.

The absurdity of this narrow reading of Simmons is most evident in a recent Fifth Circuit opinion affirming a federal conviction for a drug-related killing. In United States $v$ Flores, the court refused to apply Simmons although the defendant was ineligible for parole under the federal sentencing statute. ${ }^{63}$ The court concluded: "[b]ecause the Sentencing Guidelines vest the district court with discretion to adjust a life sentence downward, a life sentence was not the only legal sentence other than death that [the defendant] might receive." ${ }^{\text {"64 }}$ In essence, the court's opinion may be taken to mean that Simmons would never apply to a federal capital case, since the Federal Sentencing Guidelines always vest the district court with such discretion.

60 41 F3d 213, 220-22 (5th Cir 1994), cert denied 115 S Ct 1959 (1995).

61 Id at 221-22, quoting Simmons, $114 \mathrm{~S} \mathrm{Ct}$ at 2194-95 (emphasis added by Allridge).

62 Allridge, 41 F3d at 222 (internal citation omitted).

6363 F3d 1342, 1368 (5th Cir 1995), cert filed, Mar 14, 1996.

${ }^{64}$ Id at 1368. 
5. The importance of requesting a jury instruction.

Lower courts can narrow the scope of Simmons in another way. Simmons leaves unclear whether a defense counsel must request a jury instruction on parole ineligibility or whether the judge must deliver such an instruction sua sponte if the judge believes Simmons to be applicable. As noted above, the plurality in Simmons speaks broadly about the defendant's right to have the jury informed of parole ineligibility. ${ }^{65}$ The Court suggested that the judge has the responsibility to deliver the instruction even in the absence of a defense counsel request. The concurrences of Justices O'Connor and Ginsburg, however, seem to indicate that the prosecutor's argument about future dangerousness merely opens the door for the defense to rebut that argument with evidence of the defendant's parole ineligibility, where state law would otherwise prevent defense counsel from making such an argument (as in South Carolina, Pennsylvania, Virginia, Texas, and North Dakota). ${ }^{66}$

Although few courts have spoken on this issue, it could have great ramifications. Many defendants who might otherwise benefit from the rule in Simmons may be precluded from doing so because their attorneys fail to raise the argument at trial. This was evident in a recent Eleventh Circuit case in which the court dismissed a Simmons argument in a footnote. ${ }^{67}$

In sum, the Simmons decision will affect the capital sentencing procedures in only a handful of states where the jury is presented with the options of death and life imprisonment, and life imprisonment is not defined. In those states, the impact of Simmons is limited to cases in which the prosecutor puts the defendant's future dangerousness at issue, the defendant is tech-

65 See Section I.A.

${ }^{66}$ Simmons, 114 S Ct at 2199 (Ginsburg concurring); Simmons, 114 S Ct at 2200-01 (O'Connor concurring).

67 Ingram v Zant, 26 F3d 1047, 1054 n 5 (11th Cir 1994), cert denied 115 S Ct 1137 (1995) ("[The rule in Simmons] does not help [the defendant] in this case because he never requested the trial court to instruct the jury regarding the significance of life imprisonment."). See also Del Vecchio $v$ Illinois Department of Corrections, 31 F3d 1363, 1385 n 5 (7th Cir 1994), cert denied 115 S Ct 1404 (1995) ("Here Del Vecchio never requested an instruction similar to the one the South Carolina court rejected in Simmons.").

This issue is further clouded by a petitioner's argument of ineffective assistance of counsel. Is counsel ineffective for failing to raise an objection to prosecutorial and judicial conduct that was in line with the law as it stood at that time? For two different answers to that question, compare Carpenter $v$ Vaughn, 888 F Supp 658, 665 n 4 (M D Pa 1995) (recognizing the viability of Simmons claim couched in an ineffective assistance of counsel

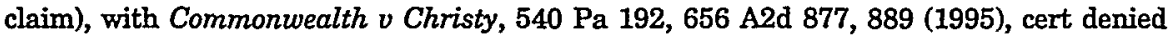
116 S Ct 194 (1995) (rejecting such a claim). 
nically ineligible for parole, and the defense attorney raises a timely objection or asks for an instruction. Since these circumstances are rare, the retroactive application of Simmons would affect only a small group of death row inmates.

\section{The Retroactivity Standard In Capital Cases}

The last Section discussed the scope of Simmons and the circumstances in which it applies on direct review. But the rule in that case will also affect some inmates whose convictions have already become final. These inmates may raise a Simmons claim if the court allows retroactive application of the rule. To understand how a court would approach the retroactivity of Simmons, it is necessary to understand the Supreme Court's current approach to retroactivity, specifically in the capital context. 28 USC $\S 2254(d)$ sets the current standard of review for all state claims. It provides that federal courts may not grant relief to state prisoners "unless the [state court] adjudication of the claim ... resulted in a decision that was contrary to, or involved an unreasonable application of clearly established Federal law, as determined by the Supreme Court of the United States."68 This is apparently a codification of Teague $v$ Lane. ${ }^{69}$ The Teague standard was then extended to capital cases in Penry $v$ Lynaugh. ${ }^{70}$ In subsequent cases, the Court further clarified the Teague standard. Teague and its progeny create a strong presumption against retroactivity, and these cases contain some strong dicta under which no rule would be applied retroactively.

6s 28 USC $\S 2254(\mathrm{~d})(1)$. For a discussion of the prior statute, see note 12.

6989 US 288 (1989). See note 12 for a discussion of the relationship between Teague and the new statute. Teague $v$ Lane sets the retroactivity standard for federal courts hearing habeas claims. State courts hearing claims under state post-conviction relief statutes are free to follow Teague or to set their own retroactivity standards even on the issue of the retroactivity of a federal constitutional rule like Simmons. See generally Mary C. Hutton, Retroactivity in the States: The Impact of Teague v. Lane on State Postconviction Remedies, 44 Ala L Rev 421 (1993) (urging states to adopt generous postconviction remedies). One group of states has acknowledged its independence on this front but has nevertheless followed Teague. See, for example, Taylor $v$ Whitley, 606 S2d 1292, 1296-97 (La 1992); State v Slemmer, 170 Ariz 174, 823 P2d 41, $48-49$ (1991); State v Zuniga, 336 NC 508, 444 SE2d 443, 446 (1994); Daniels $v$ State, 561 NE2d 487, 489 (Ind 1990); Brewer v State, 444 NW2d 77, 81 (Iowa 1989).

A few states have chosen to reject Teague. See, for example, Cowell $v$ Leapley, 458 NW2d 514, 517-18 (SD 1990); Meadows v State, 849 SW2d 748, 754-55 (Tenn 1993). This comment only examines the retroactivity of Simmons under the Teague standard; the analysis, therefore, applies to federal habeas cases and to state post-conviction cases in states following Teague.

${ }^{70} 492$ US 302, 313-14 (1989). 
Nevertheless, as this Section demonstrates, the Court has not made the Teague standard insurmountable.

\section{A. Retroactivity in Habeas Cases: Teague $v$ Lane and the "New Rule" Standard}

After years of uncertainty, the Supreme Court resolved the question of retroactivity in Teague $v$ Lane. ${ }^{71}$ In Teague, the Court set out an exacting standard for retroactivity in cases on collateral review, that is, in cases in which defendants seek to overturn their final convictions. ${ }^{72}$

Under Teague, retroactivity in habeas cases is decided as a threshold matter before looking at the merits of the case. ${ }^{73}$ According to the Court, this was the only way to treat like cases alike. ${ }^{74}$

According to Teague, courts must determine retroactivity in a two-step process. In the first step, a court must decide if the rule in question is a "new rule" or merely an extension of an old rule. If the rule is new, then it will not be applied retroactively unless it falls within one of Teague's exceptions. ${ }^{75}$ The difficult question is what constitutes a new rule. In Teague, the Court said that "a case announces a new rule when it breaks new ground or imposes a new obligation on the States or the Federal Government. . . . To put it differently, a case announces a new rule if the result was not dictated by precedent existing at the time the defendant's conviction became final."

If a court decides the rule in question is a new rule, the court must then proceed to the second step of the Teague analysis:

71489 US 288, 305-10 (1989) (plurality), citing Mackey v United States, 401 US 667, 682-84 (1971) (Harlan concurring and dissenting).

72 Dozens of critics have attacked the Teague standard. See, for example, Joseph L. Hoffmann, Retroactivity and the Great Writ: How Congress Should Respond to Teague v. Lane, 1990 BYU L Rev 183; Karl N. Metzner, Note, Retroactivity, Habeas Corpus and the Death Penalty: An Unholy Alliance, 41 Duke L J 160 (1991); Markus Dirk Dubber, Prudence and Substance: How the Supreme Court's New Habeas Retroactivity Doctrine Mirrors and Affects Substantive Constitutional Law, 30 Am Crim L Rev 1 (1992); Linda Meyer, "Nothing We Say Matters": Teague and New Rules, 61 U Chi L Rev 423 (1994). Although the Teague standard suffers from severe deficiencies, it is firmly entrenched as the law in federal habeas cases and is the leading paradigm for state retroactivity rules. Thus, this Comment address the retroactivity of Simmons under the Teague standard.

${ }_{73}$ Teague, 489 US at 300-01 (plurality).

${ }^{74}$ Id at 305 (pointing to the unfairness of treating similar retroactivity claims differently because of the time the claim reached court).

75 Id at 310.

76 Id at 301 . In subsequent cases, the Court tinkered with this definition but has still not come up with a satisfactory formulation. See Section II.B. 
determining whether the new rule falls within either of two recognized exceptions to the prohibition on the retroactive application of new rules. ${ }^{77}$ The first exception provides "that a new rule should be applied retroactively if it places 'certain kinds of primary, private individual conduct beyond the power of the criminal law-making authority to proscribe." The second exception is limited to "those new procedures without which the likelihood of an accurate [sentence] is seriously diminished."

Aside from treating like cases alike, the Court justified its strict standard on at least two other grounds. First, the Court recognized the states' strong interest in finality. ${ }^{79}$ The Court reasoned, "[w]ithout finality, the criminal law is deprived of much of its deterrent effect. The fact that life and liberty are at stake in criminal prosecutions 'shows only that "conventional notions of finality" should not have as much place in criminal as in civil litigation, not that they should have none." also noted the economic benefits of finality. The "costs imposed upon the State[s] by retroactive application of new rules of constitutional law on habeas corpus ... generally far outweigh the benefits of the application."

Second, the Court noted that the Teague standard comports with the purpose of habeas review: to serve as an incentive for trial and appellate courts to apply the constitutional standards that prevailed at the time the original proceedings took place. ${ }^{82}$ Courts cannot be asked to do any more than this.

Justice Brennan wrote a passionate and highly critical dissent. With a touch of judicial realism, Brennan noted that few

${ }^{77}$ Teague at 310-11 (plurality). These exceptions are discussed more fully in Section II.C. See also text accompanying notes 108-19.

${ }^{78}$ Id at 311.

79 Id at 308-09.

so Id at 309, quoting Henry J. Friendly, Is Innocence Irrelevant? Collateral Attack on Criminal Judgments, 38 U Chi L Rev 142, 150 (1970). The Court also quoted Justice Harlan at length on this point:

The interest in leaving concluded litigation in a state of repose, that is, reducing the controversy to a final judgment not subject to further judicial revision may, quite legitimately be found by those responsible for defining the scope of the writ to outweigh in some, many, or most instances the competing interest in readjudicating convictions according to all legal standards in effect when a habeas petition is filed.

Teague, 489 US at 306 (plurality), quoting Mackey $v$ United States, 401 US 667, 683 (1971) (Harlan concurring and dissenting).

${ }_{81}$ Teague, 489 US at 310 (plurality), quoting Solem $v$ Stumes, 465 US 638, 654 (1984).

82 Teague, 489 US at 306 (plurality). 
decisions are "dictated" by prior decisions: "Most such cases involve a question of law that is at least debatable, permitting a rational judge to resolve the case in more than one way." cause very few cases qualify under the Court's definition as new rules, "a great many cases could only be heard on habeas if the rule urged by the petitioner fell within one of the two exceptions the plurality has sketched." ${ }^{24}$ And those exceptions, Justice Brennan pointed out, are quite narrow. "The plurality's approach today can thus be expected to contract substantially the Great Writ's sweep." ${ }^{85}$ While Brennan said he approved of the majority's emphasis on treating like cases alike, he criticized the plurality's "'blind adherence" to this ideal as "letting the tail wag the dog." ${ }^{\prime 86}$ While other standards may lead to unequal treatment of defendants, Justice Brennan maintained, "it is at least arguably better that the wrong done to one person be righted than that none of the injuries inflicted on those whose convictions have become final be redressed, despite the resulting inequality in treatment. ${ }^{n 7}$

\section{B. Clarification of the Teague Standard}

Teague left many questions unanswered. In particular, commentators were left to wonder about the applicability of Teague to capital cases, ${ }^{88}$ the scope of the two exceptions, and, most importantly, what exactly constitutes a new rule.

The Court addressed these issues in subsequent cases. In Penry $v$ Lynaugh, the Court, over Justice Brennan's vehement objection, extended the Teague standard to procedural rules in capital cases. ${ }^{89}$ In the majority's view, "the finality concerns underlying Justice Harlan's approach to retroactivity are applicable

Teague, 489 US at 333 (Brennan dissenting).

st Id at 334 .

85 Id.

${ }^{86}$ Id at 327, quoting Griffith $v$ Kentucky, 479 US 314, 332 (1987) (White dissenting).

87 Id at 339 (Brennan dissenting). Of course, the ultimate irony of the Teague decision is that Teague itself announced a new rule for retroactivity.

88 Teague was not a capital case and, in a footnote, the Court said, "we need not, and do not, express any views as to how the retroactivity approach we adopt today is to be applied in the capital sentencing context." Teague, 489 US at $314 \mathrm{n} 2$ (plurality).

892 US 302, 314 (1989). Justice Brennan's objection was echoed in Steven M. Goldstein, Chipping Away at the Great Writ: Will Death Sentenced Federal Habeas Corpus Petitioners Be Able To Seek and Utilize Changes in the Law?, 18 NYU Rev L \& Soc Change 357, 401-02 (1990-91) (The Teague line of cases "will increase the likelihood that life and death will be determined in some cases not by the merits of an individual's claims but by the fortuities in the timing and pace of litigation which are beyond the individual's control."). 
in the capital sentencing context, as are the two exceptions to his general rule of nonretroactivity."

Moreover, subsequent cases revealed sharp disagreement in the Court over what constitutes a "new rule." At the center of this discord has been the inability of the justices to develop a satisfactory definition of the elusive phrase "dictated by precedent." In his Teague dissent, Justice Brennan foresaw this controversy. ${ }^{91}$

In his Butler dissent, Justice Brennan elaborated further on this idea. Quoting Justice Harlan, Justice Brennan saw that the Teague concept of "dictated by precedent" is overly narrow, and at odds with the Court's "vision of adjudication":

One need not be a rigid partisan of Blackstone to recognize that many, though not all, of this Court's constitutional decisions are grounded upon fundamental principles whose content does not change dramatically from year to year, but whose meanings are altered slowly and subtly as generation succeeds generation. ${ }^{92}$

In fact, every holding can be characterized at various levels of generality and thus cases can be distinguished on their facts. ${ }^{93}$ Justice Brennan's observations hold especially true for cases that reach the Supreme Court. If the decision in a case were so clearly "dictated" by prior precedent, the case would never even have reached the highest Court.

Penry $v$ Lynaugh, ${ }^{94}$ Butler $v$ McKellar, ${ }^{95}$ and Stringer $v$ Black ${ }^{96}$ illustrate the Court's struggles with the definition of a new rule. In Penry and Stringer, the Court took a narrow view of this category and gave a broad and generous understanding to the phrase "dictated by precedent." In Butler, however, the

90 Penry, 492 US at 314.

${ }^{91}$ See text accompanying note 83 .

${ }_{92}$ Butler, 494 US at 424 (Brennan dissenting), quoting Desist $v$ United States, 394 US 244, 263 (1969) (Harlan dissenting).

${ }_{93}$ See Meyer, $61 \mathrm{U}$ Chi L Rev at 457 (cited in note 72).

94 492 US 302 (1989).

95494 US 407 (1990).

503 US 222 (1992).

97 For a full discussion of the Court's examination of the "dictated by precedent" standard in these cases, see Meyer, $61 \mathrm{U}$ Chi L Rev at 438-40, 446-48 (cited in note 72). In Penry, Justice Scalia, concurring in part and dissenting in part, took issue with the majority's formulation: 
Court articulated its broadest definition of "new rule" to date, interpreting the Teague standard in such a way that almost nothing could fail to qualify as a "new rule."

The rhetoric of these decisions is as important as their holdings in illustrating the disagreement among the justices. In Butler, Justice Rehnquist reached the conclusion that the defendant was seeking a new rule by characterizing Teague as validating "reasonable, good-faith interpretations of existing precedents made by state courts even though they are shown to be contrary to later decisions. ${ }^{\prime 99}$ Justice Rehnquist reasoned that a rule is new if it arose from a case in which the outcome was "susceptible to debate among reasonable minds. ${ }^{100}$

Moreover, Rehnquist argued that not even a court's own characterization of its reliance on precedent matters:

[T]he fact that a court says that its decision is within the 'logical compass' of an earlier decision, or indeed that it is 'controlled' by a prior decision, is not conclusive for purposes of deciding whether the current decision is a 'new rule' under Teague. Courts frequently view their decisions as being 'controlled' or 'governed' by prior opinions even where aware of reasonable contrary conclusions reached by other courts. ${ }^{101}$

Justice Rehnquist went even further, reasoning that a disagreement among judges is evidence that something is a new rule. A circuit split, for example, is evidence that a case is "susceptible to debate among reasonable minds" and therefore announces a new rule. ${ }^{102}$

A "new rule," for purposes of Teague, must include not only a new rule that replaces an old one, but a new rule that replaces palpable uncertainty as to what the rule might be....

If Teague does not apply to a claimed "inherency" as vague and debatable as that in the present case, then it applies only to habeas requests for plain overruling-which means that it adds little if anything to the principles already in place concerning the retroactivity of new rules in criminal cases....

Penry, 492 US at 352-53 (Scalia concurring in part and dissenting in part).

${ }_{98}$ See Meyer, $61 \mathrm{U}$ Chi L Rev at 440-42 (cited in note 72). Justice Brennan again vehemently dissented: '[T] he majority would label 'new' any rule of law favoring a state prisoner that can be distinguished from prior precedent on any conceivable basis, legal or factual." Butler, 494 US at 421 (Brennan dissenting).

99 Butler, 494 US at 414. Justice Rehnquist took this language from United States $v$ Leon, 468 US 897, 918-19 (1984).

100 Butler, 494 US at 415.

101 Id.

102 Id. In Sawyer $v$ Smith, Justice Marshall responded to a similar argument. 
In Stringer, however, the Court backed off from Justice Rehnquist's dicta. The State argued, on the basis of Justice Rehnquist's opinion in Butler, that the Fifth Circuit's conclusion that the petitioner sought the benefit of a new rule demonstrated the reasonableness of the state's position. The Court, however, rejected this argument:

The Fifth Circuit's... views are relevant to our inquiry ... but not dispositive. The purpose of the new rule doctrine is to validate reasonable interpretations of existing precedents. Reasonableness, in this as in many other contexts, is an objective standard, and the ultimate decision whether [the rule] was dictated by precedent is based on an objective reading of the relevant cases. The short answer to the State's argument is that the Fifth Circuit made a serious mistake ..... 103

Wright $v$ West provided a new twist to the disagreement among the members of the Court over the meaning of Teague. Justice Thomas, writing for a three-judge plurality, described Teague as establishing a "deferential" standard of review of state court determinations of federal law. ${ }^{104}$ This notion was sharply disputed by Justice O'Connor, however, who maintained that the "reasonable jurist" inquiry was an objective one and not a deferential standard of review. In her view, deference to state court determinations of federal law is inconsistent with the purposes of habeas review. ${ }^{105}$ In a separate concurrence, Justice Kennedy refused to enter this debate, but he emphasized that Teague established a standard for retroactivity, not a standard of review. ${ }^{106}$

In its most recent Teague decisions, the Court has moved back toward its stance in Butler, focusing on whether state court

[T] he mere fact that a single court adopts a position contrary to the one dictated by our precedents does not confirm that the case law was unclear. Indeed, if that were the standard, almost every Supreme Court decision would announce a new decision, as we seldom take cases to resolve issues as to which lower courts are in universal agreement.

497 US 227, 249-50 (1990) (Marshall dissenting).

${ }^{103}$ Stringer, 503 US at 237.

104505 US 277, 291-94 (1992) (plurality).

105 See Wright, 505 US at 304 (O'Connor concurring).

${ }^{106}$ See Wright, 505 US at 307 (Kennedy concurring). In yet another separate opinion, Justice Souter merely concluded that the petitioner's claim was barred by Teague and refused to go further. See Wright, 505 US at 310 (Souter concurring). 
decisions were "reasonable," but the meaning of the terms "dictated by precedent" and "new rule" remains unsettled. ${ }^{107}$

\section{Teague's Exceptions}

Teague recognized two exceptions under which new rules could be applied retroactively. These exceptions have apparently been included in the new statute. It allows a petitioner to gain an evidentiary hearing if his claim relies on a "new rule of constitutional law, made retroactive to cases on collateral review by the Supreme Court, that was previously unavailable...."108 The first Teague exception provides "that a new rule should be applied retroactively if it places 'certain kinds of primary, private individual conduct beyond the power of the criminal law-making authority to proscribe."'109 The second exception is limited to "those new procedures without which the likelihood of an accurate conviction is seriously diminished."110

The second of these exceptions provides a possible avenue for the retroactive application of Simmons. ${ }^{111}$ In Teague, Justice O'Connor emphasized the narrow scope of this exception:

${ }^{107}$ See Graham $v$ Collins, 506 US 461, 477 (1993) ("[T]he determinative question is whether reasonable jurists reading the case law that existed in 1984 could have concluded that Graham's sentencing was not constitutionally infirm."); Gilmore $v$ Taylor, 508 US 333 (1993).

${ }^{108} 28$ USC $\S 2254(\mathrm{e})(2)$. What gaining an evidentiary hearing means to the petitioner's chances of getting relief on the basis of the "new rule" is not clear from the statute or from the legislative history. This Comment assumes it is an important step. The lack of clarity in $\S 2254(\mathrm{e})$ is just one of the statute's many flaws, a discussion of which is beyond the scope of this Comment.

${ }^{109}$ See Teague, 489 US at 311 (plurality), quoting Mackey $v$ United States, 401 US 667, 692 (1971) (Harlan concurring and dissenting). Justice O'Connor found, for example, that the declaration as a substantive matter that the Eighth Amendment prohibits the execution of mentally retarded persons fit this exception. Penry, 492 US at 314-19. The Court has not shed any further light on this exception, and its scope is not relevant to this Comment because it would not apply to Simmons.

110 Teague, 489 US at 313 (plurality). In his concurrence, Justice Stevens noted that "a touchstone of factual innocence would provide little guidance in certain important types of cases, such as those challenging the constitutionality of capital sentencing hearings." Teague, 489 US at 321 (Stevens concurring). In his dissent, Justice Brennan assumed that the second exception must also cover sentencing determinations. "In limiting the scope of the second exception to those new procedures without which the likelihood of an accurate conviction is seriously diminished,' the plurality presumably intends the exception to cover claims that involve the accuracy of the defendant's sentence as well as the accuracy of a court's determination of his guilt." Teague, 489 US at $336 \mathrm{n} 5$ (Brennan dissenting) (internal citation omitted).

11 See Teague, 489 US at 311 (plurality). 
We believe it unlikely that many such components of basic due process have yet to emerge. We are also of the view that such rules are best illustrated by recalling the classic grounds for the issuance of a writ of habeas corpus-that the proceeding was dominated by mob violence; that the prosecutor knowingly made use of perjured testimony; or that the conviction was based on a confession extorted from the defendant by brutal methods. ${ }^{112}$

In Butler, Justice Rehnquist apparently adopted this exception in death penalty cases. ${ }^{113}$

In Sawyer $v$ Smith, Justice Kennedy, concerned about undermining "the principle of finality which is essential to the operation of our criminal justice system"114 gave an even narrower definition of the second exception: "A rule that qualifies under this exception must not only improve accuracy, but also 'alter our understanding of the bedrock procedural elements' essential to the fairness of a proceeding."115 On that basis, Justice Kennedy refused to define the exception to include all new rules of capital sentencing that "preserve the accuracy and fairness of capital sentencing judgments." He explained:

It is difficult to see any limit to the definition of the second exception if cast as proposed by petitioner. All of our Eighth Amendment jurisprudence concerning capital sentencing is directed toward the enhancement of reliability and accuracy in some sense. Indeed, petitioner has not suggested any Eighth Amendment rule that would not be sufficiently "fundamental" to qualify for the proposed definition of the exception .... ${ }^{116}$

In Graham $v$ Collins, the Court appears to have extended the second exception to rules in capital sentencing procedures. ${ }^{117}$

112 Id at 313.

113 Butler, 494 US at 416, quoting Teague, 489 US at 311-13 (plurality).

114497 US 227, 242 (1990) (internal citations omitted).

115 Id, quoting Teague, 489 US at 309, 311 (plurality).

116 Sawyer, 497 US at $242-43$.

117506 US 461, 478 (1993) (apparently accepting the extension of Teague's second exception to capital sentencing cases, but finding that "the case at hand did not fall within the exception"). Justice Brennan, dissenting in Saffle $v$ Parks, offered the following justification:

If the irrevocable nature of the death penalty is not sufficient to counsel against application of Justice Harlan's doctrine of limited retroactivity for collateral review altogether, it should at least inform the determination of the proper scope of the second 
Justices Brennan and Marshall have argued that the second exception should encompass more than just "watershed rules of criminal procedure," $" 118$ particularly in capital cases. In Sawyer, Justice Marshall stated, "the notion that we have already discovered all procedures central to fundamental fairness is squarely inconsistent with our Eighth Amendment methodology, under which 'bedrock' Eighth Amendment principles emerge in light of new societal understandings and experience."

In sum, the Teague line of cases creates a strong presumption against retroactivity. But the Court has applied this presumption somewhat less aggressively than its language may at first suggest. As Penry and Stringer show, the Court has at times defined "dictated by precedent" broadly in order to give retroactive effect to rules in capital cases. Moreover, Teague's second exception, if given a broad reading, could provide another avenue for the retroactive application of Simmons.

\section{Why SIMMONS SHOULd BE APPLIED RETROACTIVELY}

This Section will first identify the confusion surrounding the retroactivity of Simmons, then survey the lower courts' treatment of the retroactivity of Simmons, and finally propose two different ways in which courts should resolve the issue in favor of retroactivity.

Lower courts examining the retroactivity of Simmons have encountered a number of problems. For instance, lower courts have wrestled with Teague's mandate that retroactivity be treated as a threshold issue. In Teague, the Court announced that courts should determine whether the rule sought by the defendant meets the Teague retroactivity standard before deciding whether the rule applies in the particular instance. Several lower courts have failed to obey this edict and have first found a defendant's claim to be outside the scope of Simmons and then

Teague exception in capital cases. Moreover, the majority's insistence that a rule must enhance the accuracy of the factfinding process in order to fit within the second exception is difficult to justify in the context of capital sentencing.

494 US 484, 505-06 (1990) (Brennan dissenting) (footnotes omitted).

118 Parks, 494 US at 505 (Brennan dissenting), quoting Teague, 489 US at 311.

119 Sawyer, 497 US at 257 (Marshall dissenting). See also Parks, 494 US at 506 n 8 (Brennan dissenting), quoting Ake v Oklahoma, 470 US 68, 87 (1985) (Burger concurring) ("In capital cases, the finality of the sentence imposed warrants protections that may or may not be required in other cases."). 
stated as an afterthought that even if the defendant had a valid Simmons claim, that claim would be barred by Teague. ${ }^{120}$

In essence, those courts are making substantive judgments about the scope of the Simmons rule, when they should not even be reaching the substance of the claims. In a concurring opinion in a recent Fourth Circuit case, Judge Luttig pointed out the majority's contravention of the Supreme Court's directive and explained two dangers of this practice. ${ }^{21}$ First, the failure to treat retroactivity as a threshold matter "relegat[es] the Supreme Court's decision in Teague $v$. Lane in this circuit to a rule of little or no practical consequence." ${ }^{\text {222 }}$ Moreover,

the methodology employed by the majority gives panels of this court license to issue what in essence are advisory opinions on significant constitutional questions which, because they are Teague-barred, are not even cognizable on federal habeas. Here, for example, our circuit is henceforth bound by the majority's interpretation of Simmons ... when the scope of that decision is not even properly before the court. ${ }^{123}$

The lower courts that have addressed the retroactivity of Simmons have come to quite different results. The Fifth Circuit $^{124}$ and the Pennsylvania Supreme Court ${ }^{125}$ have refused to apply Simmons retroactively. The Fourth Circuit would probably not apply Simmons retroactively either. ${ }^{126}$ The Supreme Court of New Mexico ${ }^{127}$ and district courts in Pennsylvania, ${ }^{128}$

${ }^{120}$ See, for example, Johnson $v$ Scott, 68 F3d 106, 111-12 n 11 (5th Cir 1995), cert denied 64 USLW 3656 (1996) (After rejecting Johnson's claim on the merits, the court noted that "even if Simmons applied to Johnson's case, it would still be barred by Teague."); Allridge v Scott, 41 F3d 213, 222 n 11 (5th Cir 1994), cert denied 115 S Ct 1959 (1995) (same).

${ }^{121}$ Townes v Murray, 68 F3d 840, 855-56 (4th Cir 1995), cert denied 116 S Ct 831 (1996) (Luttig concurring) (citations omitted).

122 Id at 856.

${ }^{123} \mathrm{Id}$.

${ }^{124}$ See Allridge, 41 F3d at 222 n 11 ("In addition to failing on the merits, Allridge's Simmons claim would be barred under the non-retroactivity limitation the Supreme Court announced in Teague $v$. Lane...") (citations omitted); Johnson, 68 F3d at 111-12 n 11; Montoya $v$ Scott, 65 F3d 405, 416-17 (5th Cir 1995), cert denied 64 USLW 2439 (1996).

${ }_{125}$ See Commonwealth v Christy, $540 \mathrm{~Pa} 192,656$ A2d 877, 888-89 (1995).

${ }^{126}$ See Townes, 68 F3d at 850 . Because the court held that Simmons did not apply to the facts of Townes's case (ignoring the Supreme Court's direction to deal with retroactivity as a threshold issue) the court had "no occasion to determine whether Simmons established a 'new rule' for purposes of federal habeas review and, if so, whether the rule there announced falls within the second Teague exception." Id. The court did hold that the "broader rule" sought by Townes should not be applied retroactively under the Teague test. Id at 853 .

${ }_{127}$ See Clark v Tansy, 118 NM 486, 882 P2d 527, 531-34 (1994). 
Virginia, ${ }^{129}$ and Illinois, ${ }^{130}$ however, have all applied the rule retroactively-and the Seventh Circuit might do so in the future. ${ }^{131}$

\section{A. Why Simmons Is Not a "New Rule"}

Before offering an analysis of how Simmons was compelled by Gardner and Skipper, and thus ought to be applied retroactively, it is necessary to examine-and discard-some obvious arguments for and against the retroactivity of Simmons.

First, any argument in favor of retroactivity must overcome Supreme Court dicta indicating that disagreement among judges as to a rule's "newness" is sufficient evidence that the rule is "new" for Teague purposes. According to the logic of Justice Rehnquist's Butler dictum, the dissenting opinion of Justice Scalia-which Justice Thomas joined-proves that Simmons was susceptible to debate among reasonable jurists. ${ }^{132}$

Justice Scalia's dissent does not demonstrate such a debate. In fact, Justice Scalia acknowledges the central logic of the plurality's opinion-that a defendant may not be sentenced to death on the basis of information he had no opportunity to deny or explain. What Justice Scalia does dispute, however, is whether Simmons presents such a factual situation. ${ }^{133}$ Since Justice Scalia's dissent was really based on factual grounds, the Court seems to have unanimously recognized at least a narrow rule allowing the defendant to raise parole ineligibility when the prosecutor builds his case for death on an argument of future dangerousness outside of prison.

Similarly, one might argue that the disagreement between the courts that have found Simmons to be a new rule and those that have found it not to be a new rule shows that the issue is susceptible to debate and is, therefore, "new." The Court, howev-

\footnotetext{
${ }^{128}$ Carpenter $v$ Vaughn, 888 F Supp 658, 665-66 (M D Pa 1995).

129 O'Dell $v$ Thompson, C.A. No. 3:92CV480 (E D Va Sept 6 1994).

130 See note 131.
}

131 In Stewart $v$ Lane, the court decided not to apply Simmons retroactively because at the time Stewart's conviction became "final," the Supreme Court had not handed down Skipper. 60 F3d 206, 300-02 (7th Cir 1995), cert petition filed Jan 16, 1996. The Stewart court noted: "We might have been presented with a different case if Stewart's convictions had become final after the Supreme Court decided Skipper, because it is arguable that Skipper compels the result in Simmons." Id at 302 n 4. In Spreitzer v Peters, the Northern District of Illinois seized upon this very footnote to apply Simmons retroactively. 1996 US Dist LEXIS $1189 * 11-12,13$ (N D IIl).

${ }^{132}$ See Butler, 494 US at 415.

133 See text accompanying note 41 . 
er, rejected this argument in Stringer, where Justice Kennedy found that the rule at issue in that case was not new despite the Fifth Circuit's views to the contrary. ${ }^{134}$

Thus, the argument that any disagreement between courts or judges means that a rule is a new rule does not preclude retroactive application of Simmons. The argument that Simmons should be applied retroactively, however, cannot rely on the reasoning of the courts that have decided to apply it retroactively.

The New Mexico Supreme Court, for example, applied Simmons retroactively without even making a retroactivity inquiry. ${ }^{135}$ The Middle District of Pennsylvania and the Eastern District of Virginia did go through the proper Teague analysis, but both courts based their decisions largely on the plain language of Justice Blackmun in Simmons that "the principle announced in Gardner was reaffirmed in Skipper, and compels our decision today." ${ }^{136}$ Although this statement seems to provide strong evidence that Simmons was compelled by Gardner and Skipper, the Supreme Court has made clear that such statements are not dispositive. Recall that, in Butler, the Court specifically repudiated this justification for the retroactive application of a rule-at least with regard to such statements by lower court judges. ${ }^{137}$ Indeed, one might wonder if the same analysis applies to the Supreme Court's characterization of its own precedent.

Thus, Justice Scalia's dissent, lower court opinions denying and permitting retroactive application of Simmons, and Justice Blackmun's statement in Simmons are not dispositive. Ultimately, then, the retroactivity of Simmons must depend instead upon the relationship of Simmons to Gardner and Skipper, the two

134 See text accompanying note 103. The Court was wise to back away from Justice Rehnquist's stance. The practice of considering the opinions of lower courts as evidence of newness is dangerous. When these lower court opinions are taken into account, Teague creates a vicious circle in which every rule is new. Given the Court's high standard for retroactivity (and the Teague standard's lack of clarity), a lower court will be inclined not to give any rule retroactive effect. If the Supreme Court then turns around and uses that lower court's denial of retroactivity as evidence of "newness," everything will be a new rule.

${ }^{135}$ See Clark v Tansy, 118 NM 486, 882 P2d 527, 531-33 (1994).

${ }^{136}$ Carpenter $v$ Vaughn, 888 F Supp 658, 666 (M D Pa 1995), quoting Simmons, $114 \mathrm{~S}$ Ct at 2194 (emphasis added). The court in Spreitzer $v$ Peters, 1996 US Dist LEXIS 1189, *9-17 (N D IIl), also relied on this statement but went on to conduct a careful analysis of the relationship of Simmons to its precedents.

137 Butler, 494 US at 415 . See also text accompanying note 102. Justice Rehnquist argued that a court's own characterization of its reliance on precedent "is not conclusive for purposes of deciding whether [a decision] is a 'new rule' under Teague." Id. Justice Rehnquist made this argument about the statements of lower court judges. 
precedents upon which it chiefly relies. ${ }^{138}$ Under Teague, Simmons must be applied retroactively if it was compelled by Gardner and Skipper. The holdings of Gardner and Skipper both foreshadow Simmons. ${ }^{139}$ In Skipper, the Court stated that the exclusion of evidence of the defendant's good behavior in prison during the penalty phase of his capital trial "impeded the sentencing jury's ability to carry out its task of considering all relevant facets of the character and record of the individual offender." Court noted:

Where the prosecution specifically relies on a prediction of future dangerousness in asking for the death penalty, it is not only the rule of Lockett and Eddings that requires that the defendant be afforded an opportunity to introduce evidence on this point; it is also the elemental due process requirement that a defendant not be sentenced to death "on the basis of information which he had no opportunity to deny or explain." ${ }^{141}$

Certainly Simmons can be distinguished from these cases on factual grounds. But a reasonable jurist cannot deny that the outcome of Simmons was dictated by those two cases. In both Gardner and Simmons, the sentencer sentenced the defendant to death on the basis of information that he was not given the opportunity to rebut. Skipper is based on the Lockett/Eddings line of cases which mandate that in capital sentencing cases "the sentencer [must] not be precluded from considering, as a mitigating factor, any aspect of a defendant's character or record and

${ }^{138}$ Under the Teague analysis, the reviewing court must examine the state of the law on the date the petitioner's conviction became final. A state conviction and sentence become final for Teague purposes "when the availability of direct appeal to the state courts has been exhausted and the time for filing a petition for a writ of certiorari has elapsed or a timely filed petition has been finally denied." Caspari $v$ Bohlen, 114 S Ct 948, 953 (1994). Thus, if a petitioner's conviction became final in 1985, he could not argue that Skipper, which was decided in 1986, compelled Simmons. See note 131. The new habeas statute might alter this analysis slightly. It says nothing about looking at the state of the law when the conviction became final. It only asks if the state court adjudication was "reasonable." Arguably, this means that the habeas court must look at the state of the law at the time the state post-conviction court denied relief. If this is so, then under the new statute, the petitioner can benefit from any decisions handed down between the time his conviction became final and the time his post-conviction relief is denied, whereas under Teague he could not.

${ }^{239}$ Gardner, 430 US at 362.

${ }^{140}$ Skipper, 476 US at 8.

${ }^{141}$ Id at 5 n 1, quoting Gardner, 430 US at 362. 
any of the circumstances of the offense that the defendant proffers as a basis for a sentence less than death." 142 It is difficult to read this language and yet conclude that parole evidence is not "an aspect of the defendant's record" that the sentencer must be allowed to consider. "Skipper not only left little doubt that a capital defendant has the right to present his sentencer with any and all evidence that might mitigate his punishment, but was also very clear that testimony regarding a defendant's probable future conduct was such evidence."143

Policy arguments also favor the retroactive application of Simmons. First, although the application of Teague in the capital context is clearly established, one might wonder about the wisdom of this decision. Teague's policy justifications-finality and equality-are less persuasive when a person's life is at stake. As Justice Brennan wrote in his dissent in Penry, the extension of Teague to capital cases

means that a person may be killed although he or she has a sound constitutional claim that would have barred his or her execution had this Court only announced the constitutional rule before his or her conviction and sentence became final. It is intolerable that the difference between life and death should turn on such a fortuity of timing, and beyond my comprehension that a majority of this Court will so blithely allow a State to take a human life though the method by which sentence was determined violates our Constitution. ${ }^{144}$

In light of this reasoning, perhaps the Court should be at least somewhat more lenient in its application of Teague to capital cases.

${ }^{142}$ Skipper, 476 US at 4, quoting Eddings $v$ Oklahoma, 455 US 104, 110 (1982), quoting Lockett $v$ Ohio, 438 US 586, 604 (1978) (plurality) (emphasis in Lockett). On the basis of this language, it is difficult to see how the Court avoided Justice Souter's Eighth Amendment position in Simmons. Parole status would seem to be an "aspect of the defendant's record" as contemplated by Lockett and Eddings. See text accompanying notes 33-35.

${ }^{143}$ Spreitzer, 1996 US Dist LEXIS $1189 * 14-15$.

${ }_{144}$ Penry, 492 US at 341 (Brennan dissenting). 
Second, despite fears to the contrary, ${ }^{145}$ the retroactive application of Simmons would not open the prison gates to release a flood of our country's most violent criminals. First, those who would benefit would only have their sentences, not their convictions, reversed. These defendants would receive a new sentencing hearing. Moreover, the number of prisoners who would receive a new sentencing hearing is relatively small, because, as Section II demonstrated, the lower courts have given Simmons a very narrow reading. Even if Simmons were given retroactive effect, apparently, an inmate on death row could only prevail on a Simmons claim if the prosecutor built his case for the death penalty on the defendant's future dangerousness, the defendant was statutorily ineligible for parole, the defense counsel preserved the defendant's constitutional right with an objection, and the jury, of course, was not informed of the defendant's parole status. This point deserves emphasis: only five states-Pennsylvania, Virginia, Texas, South Carolina, and North Dakota-give the jury the option of a life sentence without parole but do not inform the jury about the defendant's parole ineligibility. ${ }^{146}$ Thus, the retroactive application of Simmons would only provide relief to a small number of inmates in a handful of states.

Finally, not applying Simmons retroactively would mean that prosecutorial misconduct would go unpunished. There is no conceivable justification for a prosecutor to build his case for the death penalty on the defendant's future dangerousness to society at large when the prosecutor knows that the defendant will never be paroled if given a life sentence. ${ }^{147}$

B. Why Simmons Should Be Applied Retroactively Under Teague's Second Exception Even If It Is a "New Rule"

Even if Simmons were not compelled by prior precedent and states a "new rule" under Teague, Simmons provides a context for the Court to reconsider the scope of Teague's second exception

${ }^{145}$ In Commonwealth $v$ Christy, Justice Flaherty noted, "One cannot ignore the effect of retroactive application of Simmons to collaterally attacked sentences. Should we hold otherwise, it is not unreasonable to anticipate that almost every death sentence imposed in Pennsylvania would be subject to collateral attack on the basis of Simmons." $540 \mathrm{~Pa}$ 192, 656 A2d 877, 889 n 23 (1995), cert denied 116 S Ct 194 (1995).

146 See note 53 and accompanying text.

147 In his Sawyer dissent, Justice Marshall made a similar point. "The state prosecutor ... surely could not claim a good-faith belief in the legitimacy of the conduct proscribed in Caldwell-misleading and inaccurate argument designed to minimize the jury's sentencing responsibility." 497 US at 258 (Marshall dissenting). 
and apply Simmons retroactively. This exception apparently has been included in the new habeas statute. ${ }^{148}$ As noted above, the second exception provides for the retroactive application of "those new procedures without which the likelihood of an accurate conviction is seriously diminished." Although the Court has been careful to emphasize the narrow scope of this exception, ${ }^{150}$ the Court has recognized that accurate sentencing may be included under this exception. ${ }^{151}$ Even in the capital sentencing context, such rules "must not only improve accuracy, but also 'alter our understanding of the bedrock procedural elements' essential to the fairness of a proceeding."152

Justice Brennan and Justice Marshall, however, have suggested a broader understanding of the second exception-an understanding that the Court should seriously consider. In his Parks dissent, Justice Brennan argued that "the irrevocable nature of the death penalty ... should ... inform the determination of the proper scope of the second Teague exception in capital cases." J153 Justice Brennan noted that the Supreme Court "has consistently 'recognized that the qualitative difference of death from all other punishments requires a correspondingly greater degree of scrutiny of the capital sentencing determination."'154 In Sawyer, Justice Marshall also argued that the second exception should be broader. ${ }^{155}$

Parks, like Simmons, dealt with possible mitigating evidence. Justice Brennan concluded:

Rules ensuring the jury's ability to consider mitigating evidence guarantee that the jury acts with full information when formulating a moral judgment about the defendant's conduct. Because such rules are integral to the proper func-

148 See note 15 and accompanying text.

149 Teague, 489 US at 313 (plurality). See also note 110.

${ }^{150}$ See text accompanying note 112.

151 In rejecting the application of the second exception in Graham $v$ Collins, 506 US 461, 478 (1993), Justice White wrote, "We do not believe that denying Graham special jury instructions concerning his mitigating evidence of youth, family background, and positive character traits 'seriously diminish[ed] the likelihood of obtaining an accurate determination' in his sentencing proceeding." Id, quoting Butler, 494 US at 416 (emphasis added).

${ }^{152}$ Sawyer, 497 US at 242, quoting Teague, 489 US at 311 (plurality), quoting Mackey, 401 US at 693.

153 Parks, 494 US at 505-06 (Brennan dissenting).

154 Id at 505, quoting California $v$ Ramos, 463 US 992, 998-99 (1983).

${ }^{255}$ Sawyer, 497 US at 257 (Marshall dissenting). 
tioning of the capital sentencing hearing, they must apply retroactively under the second Teague exception. ${ }^{156}$

A similar argument can be made about Simmons, particularly in light of the clear empirical data relating to a jury's understanding of "Tife in prison."157 The importance of this cannot be overstated. Withholding accurate sentencing information from capital juries can and does influence the outcome of trials. Empirical studies concerning the effect of not informing jurors that "life" means "life without parole" have shown that a typical juror believes that a life sentence carries with it a possibility of parole, and, as a result, is more likely to sentence the defendant to death. ${ }^{158}$ If inmates really sit on death row as a result of a judge's refusal to remedy a misleading prosecutorial argument with accurate sentencing information, then the Simmons rule should be applied retroactively under the second exception.

\section{CONCLUSION}

The information a jury has about a defendant's parole status can mean the difference between a life sentence and the death penalty. In Simmons, the Supreme Court recognized this and came to the common-sense conclusion that a prosecutor cannot mislead a jury with an argument about the defendant's future dangerousness when, in reality, the jury's only other sentencing option-a life sentence-means the defendant will never again walk the streets. Even under the Supreme Court's strict Teague standard, codified in 28 USC \& 2254(d), this rule should be applied retroactively to defendants who sit on death row as a result of this kind of prosecutorial argument. As a legal matter, Simmons is not a new rule of law but was plainly dictated by Skipper and Gardner. Moreover, several policy arguments favor retroactive application. Since lower courts have interpreted the rule announced in Simmons narrowly, retroactive application will not mean a flood of claims. Furthermore, prosecutors should not go unpunished for making misleading arguments outlawed by Simmons. Finally, a "fortuity of timing" should not make the difference between life and death. 
. 